\title{
PERANAN MEDIA VIDEO DALAM MENINGKATKAN AKTIVITAS SISWA PADA PEMBELAJARAN IPS DI KELAS V SDN MAMPANG PRAPATAN O2 PAGI
}

\author{
Oleh : Ika Yatri ${ }^{1)}$ Lanjar Pratiwi $^{2}$ \\ Universitas Muhammadiyah Prof. Dr. Hamka ${ }^{1,2)}$
}

\begin{abstract}
ABSTRAK
Mata pelajaran IPS bertujuan untuk membina siswa menjadi warga negara yang baik, yang memiliki pengetahuan, keterampilan, dan kepedulian sosial. Tujuan dari penelitian ini adalah untuk meningkatkan aktivitas siswa kelas V SDN Mampang Prapatan 02. Jenis penelitian ini adalah penelitian tindakan kelas melalui peranan media video dan dilaksanakan dalam tiga siklus. Setiap siklus terdiri dari empat tahapan yaitu perencanaan (planning), aksi atau tindakan (acting), observasi (observing), dan refleksi (reflecting). Subyek penelitian yaitu guru dan siswa kelas V SDN Mampang Parpatan 02 Jakarta Selatan tahun Pelajaran 2016/2017, dengan jumlah siswa sebanyak 24 orang anak terdiri dari 13 siswa laki-laki dan 11 siswa perempuan. Fokus penelitian adalah aktivitas siswa. Teknik pegumpulan data menggunakan tes, observasi dan dokumentasi. Hasil penelitian menunjukkan bahwa peranan media video dapat meningkatkan aktivitas siswa pembelajaran IPS. Rata-rata skor aktivitas siswa siklus I yaitu 27,75 dengan kategori cukup, siklus II yaitu 32,25 dengan kategori baik, dan siklus III yaitu 33,625 dengan kategori sangat baik. Hasil belajar siswa meningkat dapat dilihat dari pra siklus dengan rata-rata kelas 55,83, ketuntasan klasikal 16,66\% siklus I dengan rata-rata kelas 58,33, ketuntasan klasikal 29,10\%, siklus II dengan rata-rata 68,75, ketuntasan klasikal 66,60\%, dan siklus III dengan rata-rata kelas 80,83 dengan ketuntasan klasikal 91,42\%. Berdasarkan analisis hasil penelitian tindakan kelas tersebut dapat disimpulkan, bahwa pembelajaran IPS melalui peranan media video dapat meningkatkan aktivitas siswa dan berbanding lurus dengan hasil belajar siswa. Saran bagi guru adalah guru dapat menerapkan media video untuk meningkatkan aktivitas pembelajaran.
\end{abstract}

Kata kunci: Pembelajaran IPS, Aktivitas Siswa, Peranan Media Video

\section{PENDAHULUAN}

Pendekatan dalam pembelajaran yang dilakukan di SD masih seringkali dijumpai berpusat pada guru (teacher centered). Padahal hal tersebut membuat siswa lebih mudah bosan dan tidak memahami materi dikarenakan pembelajaran yang monoton. Pembelajaran yang monoton menyebabkan belajar siswa di dalam kurang maksimal. Padahal proses belajar siswa yang aktif sangatlah mempengaruhi hasil belajar. Jika teacher centered terus diterapkan akan menjadikan mereka sebagai subyek belajar yang menerima pembelajaran tanpa ikut terlibat di dalamnya. Tujuan pendidikan IPS menurut Sumaatmadja, dalam Hidayati (2008: 1.24) adalah membina anak didik menjadi warga negara yang baik, yang memiliki pengetahuan, keterampilan, dan kepedulian sosial yang berguna bagi dirinya serta bagi masyarakat dan Negara. Untuk emncapai ujuan IPS tersebut, 
seorang guru harus mampu memfasilitasi siswa agar menjadi warga Negara yang baik melalui proses pembelajaran di kelas.

Berdasarkan studi pendahuluan di kelas VB SDN Mampang Prapatan 02 Pagi, menunjukkan bahwa pada saat pembelajaran IPS guru masih seringkali mendominasi dan model pembelajaran masih kurang tepat sesuai dengan kondisi siswa. Mata pelajaran IPS di kelas V cakupan materi sangat luas dan banyak menggunakan hafalan terutama materi sejarah di kelas V SD. Hal tersebut membuat tingkat pemahaman siswa dalam materi sejarah sangatlah rendah, padahal pemahaman materi berpengaruh terhadap nilai siswa.

Sesuai dengan data hasil belajar dan pelaksanaan pembelajaran IPS di atas, perlu adanya penerapan media pembelajaran yang inovatif dalam meningkatkan aktivitas siswa dalam pembelajaran IPS yang sesuai dengan standar kurikulum dan standar proses. Aktivitas menurut Kamus Besar Bahasa Indonesia adalah kegiatan atau keaktifan. Dalam belajar sangat diperlukan adanya aktivitas, tanpa aktivitas belajar itu tidak mungkin akan berlangsung dengan baik (Sardiman, 2010: 95). Pembelajaran IPS pada kelas V SD mengandung konsep abstrak sehingga diperlukan media untuk membuat konsep menjadi lebih konkret dan mudah dipahami oleh siswa. Keunggulan media video yang mampu menampilkan gambar bergerak dan suara merupakan satu daya tarik sendiri, karena siswa mampu menyerap pesan atau informasi dengan menggunakan lebih dari satu indera (Daryanto, 2010: 88). Untuk itu penggunaan media yang tepat merupakan suatu usaha untuk menyiapkan kondisi belajar yang lebih baik yang pada akhirnya dapat meningkatkan aktivitas siswa dalam pembelajaran IPS. Penggunaan media dapat membuat pembelajaran menjadi lebih efektif. Pembelajaran dikatakan efektif jika siswa dapat memahami materi yang dipelajari sehingga berbanding lurus dengan hasil belajar kognitif yang diperoleh bisa meningkat dengan sendirinya. Salah satunya adalah dengan menerapkan media video pembelajaran. Media video pembelajaran IPS dibuat menggunakan software pinnacle.

\section{METODE PENELITIAN}

Penelitian yang digunakan dalam penelitian ini adalah penelitian tindakan kelas (PTK). PTK atau Classroom Action 
Research (CAR) yaitu suatu penelitian tindakan yang dilakukan di kelas. PTK merupakan suatu pencermatan terhadap kegiatan belajar berupa sebuah tindakan, yang sengaja dimunculkan dan terjadi dalam sebuah kelas secara bersama (Arikunto, 2014: 2). Subyek penelitian ini adalah guru kelas VB, siswa kelas VB SDN Mampang Prapatan 02 Pagi Jakarta Selatan sebanyak 24 orang, tahun ajaran 2016/2017.

Salah satu kegiatan yang penting dalam PTK adalah pengumpulan data yang dibutuhkan. Teknik pengumpulan data pada penelitian ini, yaitu tekni tes dan teknik non tes. Menurut Arikunto (2006: 150) tes adalah serentetan pertanyaan atau latihan atau alat lain yang digunakan untuk mengukur keterampilan, pengetahuan, intelegensi, kemampuan atau bakat yang dimiliki oleh individu atau kelompok.. Tes dalam penelitian ini digunakan untuk mengukur kemampuan belajar siswa dalam pembelajaran IPS menggunakan media video. Srdangkan teknik non tes dalam penelitian ini yaitu observasi dan wawancara. Observasi dalam penelitian digunakan untuk menggambarkan aktivitas siswa dalam proses pembelajaran menggunakan media video. Dalam penelitian ini wawancara digunakan untuk mengambil data awal dalam identifikasi masalah.

Prosedur penelitian ini menggunakan penelitian tindakan kelas dengan tiga siklus. Masing-masing siklus terdiri dari empat kegiatan yaitu: perencanaan (planning), tindakan (acting), observasi (observation), dan refleksi (reflecting). Setiap siklus dilaksanakan sesuai dengan optimalnya hasil belajar IPS kelas V. dengan melakukan observasi terhadap pembelajaran yang dilakukan oleh guru dan aktivitas siswa di dalam kelas.

Instrumen penelitian dalam penelitian ini adalah lembar observasi dan soal tes. Observasi dilakukan dengan menggunakan lembar observasi yang telah disusun. Lembar observasi ini berbentuk check-list dengan pilihan "ya" atau "tidak". Lembar ini dipergunakan untuk mengetahui apakah dengan menggunakan media video pembelajaran dapat meningkatkan aktivitas siswa kelas VB SDN Mampang Prapatan 02 Pagi berjalan dengan baik ataukah tidak. Tes dilaksanakan setiap akhir siklus, hal ini dimaksudkan untuk mengukur hasil yang diperoleh siswa setelah pemberian tindakan. Tes dilaksanakan secara individu dan berupa soal uraian sebanyak 10 butir soal. Untuk menganalisis 
pembelajaran IPS terlebih dahulu diuji cobakan agar diperoleh butir soal yang baik sebelum diberikan kepada siswa. Butir soal yang baik harus memenuhi kriteria valid dan reliabel serta diuji tingkat kesukaran dan daya pembeda.

Validitas adalah suatu ukuran untuk menunjukan tingkat kevalidan atau kesahihan suatu instrumen penelitian. Menurut Sugiono (2010: 177) untuk menguji validitas konstruk dilakukan dengan cara mengkorelasikan antara skor butir pertanyaan dengan skor totalnya. Rumus yang digunakan untuk menguji validitas tes evaluasi adalah product moment dari Karl Pearson dengan rumus sebagai berikut:

$r_{x y}=\frac{n \sum x y-\left(\sum x\right)\left(\sum y\right)}{\sqrt{\left(n \sum x^{2}-\left(\sum x\right)^{2}\right\}\left\{n \sum y^{2}-\left(\sum y\right)^{2}\right\}}}$

Keterangan :

$\mathrm{r}_{\mathrm{xy}} \quad$ : Koefisien korelasi antara

variabel $\mathrm{X}$ dan variabel $\mathrm{Y}$.

$\Sigma \mathrm{X} \quad$ : Jumlah skor item

$\Sigma y \quad$ : Jumlah skor total (seluruh item)

$\mathrm{n} \quad$ : Jumlah responden

Reliabilitas perangkat tes dihitung untuk mengetahui sejauh mana hasil suatu pengukuran dapat dipercaya. Hasil pengukuran dapat dipercaya apabila dalam beberapa kali pelaksanaan pengukuran terhadap kelompok subjek yang sama diperoleh hasil yang relatif sama dan belum berubah. Dalam hal ini, relatif sama berarti tetap adanya toleransi terhadap perbedaan-perbedaan kecil diantara hasil beberapa kali pengukuran (Azwar, 2013: 7). Setelah diperoleh $r_{11}$, selanjutnya hasilnya disesuaikan dengan criteria koefisien reliabilitas. Berikut adalah tabel kriteria koefisien reliabilitas

Tabel 1. Kriteria Koefisien Reliabilitas

\begin{tabular}{cc}
\hline Kriteria & $\begin{array}{c}\text { Nilai } \\
\text { Reliabilitas }\end{array}$ \\
\hline$r_{i} \geq r_{\text {tabel }}$ & Reliabel \\
$r_{i}<r_{\text {tabel }}$ & Tidak Reliabel \\
\hline
\end{tabular}

Selanjutnya butir soal diuji menggunakan indeks tingkat kesukaran pada umumnya dinyatakan dalam bentuk proporsi yang besarnya berkisar 0,00 1,00. Dengan mengetahui indeks kesukaran soal dapat diperoleh informasi tentang kejelekan soal dan digunakan sebagai acuan untuk mengadakan perbaikan. Tingkat kesukaran (p) sebenarnya merupakan nilai rata-rata dari kelompok peserta tes, oleh karena itu tingkat kesukaran ( $p$ ) sebenarnya adalah rata-rata dari suatu distribusi skor kelompok dari suatu soal (Surapranata, 
2005: 19). Setelah diperoleh tingkat kesukaran, kemudian hasilnya disesuaikan dengan tabel criteria indeks kesukaran. Berikut adalah Kriteria untuk menginterpretasikan indeks kesukaran menurut Arikunto (2013: 225) adalah sebagai berikut.

Tabel 2. Kriteria Indeks Kesukaran

Menurut Surapranata (2005: 23), indeks daya pembeda merupakan indeks yang digunakan dalam membedakan antara peserta tes yang berkemampuan tinggi dengan peserta tes yang berkemampuan rendah. Indeks ini menunjukkan kesesuaian antara fungsi soal dengan fungsi tes secara keseluruhan. Soal yang memiliki validitas soal di atas 0,40 merupakan soal yang baik.

Setelah diperoleh hasil daya pembeda $(D P)$, selanjutnya hasilnya diklasifiaksikan menggunakan tabel klasifikasi daya pembeda untuk

\begin{tabular}{cc}
\hline Kriteria & $\begin{array}{c}\text { Nilai Indeks } \\
\text { Kesukaran }\end{array}$ \\
\hline $\mathrm{TK}<0,30$ & Soal Sukar \\
$0,30 \leq \mathrm{TK} \leq 0,70$ & Soal Sedang \\
$\mathrm{TK}>0,70$ & Soal Mudah \\
\hline mengetahui apakah & hasilnya itu jelek, \\
cukup, baik, baik sekali ataukah butir soal \\
dibuang.
\end{tabular}

Tabel 3. Klasifikasi Daya Pembeda

\begin{tabular}{cc}
\hline Nilai Daya Pembeda & Kriteria \\
\hline $0,00-0,20$ & Jelek \\
$0,20-0,40$ & Cukup \\
$0,40-0,70$ & Baik \\
$0,70-1,00$ & Baik Sekali \\
Negatif & Soal dibuang \\
\hline
\end{tabular}

Metode analisis data yang Menentukan skor tertinggi; digunakan dalam penelitian ini Mencari median; dan (4) Membagi adalah kuantitatif dan kualitatif. rentang nilai menjadi 4 kategori yaitu Untuk mengetahui data aktivitas siswa dengan menggunakan kriteria menurut Herrhyanto (2007: 5.3-5.4) dalam mengolah data skor dapat dilakukan langkah sebagai berikut: sangat baik, baik, cukup dan kurang). Nilai yang didapat dari lembar observasi kemudian dimasukkan dalam tabel kriteria ketuntasan data kualitatif.

(1) Menentukan skor terendah; (2) 
Tabel 4. Kriteria Ketuntasan Data Kualitatif

\begin{tabular}{ccc}
\hline Kriteria Ketuntasan & Skala Penilaian & Kualifikasi \\
\hline $\mathrm{Q} 3 \leq$ skor $\leq \mathrm{T}$ & Sangat Baik & Tuntas \\
$\mathrm{Q} 2 \leq$ skor $<$ Q3 & Baik & Tuntas \\
$\mathrm{Q} 1 \leq$ skor $<$ Q2 & Cukup & Tidak Tuntas \\
$\mathrm{R} \leq$ skor $<$ Q1 & Kurang & Tidak Tuntas \\
\hline \multicolumn{2}{r}{ (Kreatif Jurnal Kependidikan Dasar, 2011: 320) }
\end{tabular}

Data kuantitatif berupa data hasil belajar siswa pada aspek kognitif, kemudian dianalisis dengan menggunakan teknik analisis deskriptif dengan menentukan ratarata dari hasil belajar siswa. Menurut Poerwanti (2008: 6-15) skala 100 berangkat dari persentase yang mengatikan skor prestasi sebagai proporsi penguasaan siswa pada suatu perangkat tes dengan batas minimal angka 0 sampai $100 \%$. Data hasil belajar siswa dapat dianalisis secara kuantitatif untuk memperoleh kesimpulan dengan menggunakan tabel 5 sebagai berikut.

Tabel 5. Kriteria Tingkat Keberhasilan Belajar Siswa dalam Persen (\%)

\begin{tabular}{cc}
\hline Tingkat Keberhasilan $\%$ & Kualifikasi \\
\hline$>80 \%$ & Sangat Tinggi (SB) \\
$60-79 \%$ & Tinggi (B) \\
$40-59 \%$ & Sedang (C) \\
$20-39 \%$ & Rendah (K) \\
$<20 \%$ & Sangat Rendah \\
\hline & (Aqib, 2010:41
\end{tabular}

Indikator ketercapaian dalam penelitian ini adalah sebagai berikut: (1) Minimal $60 \%$ siswa aktif dalam KBM; (2) Ketuntasan belajar individual mencapai skor $65 \%$; dan (3) $75 \%$ siswa kelas VB Mampang
Prapatan 02 Pagi mengalami ketuntasan secara klasikal, artinya 75\% dari siswa mencapai nilai KKM yaitu 70. 


\section{HASIL DAN PEMBAHASAN}

$\begin{array}{llr}\text { Penerapan } & \text { media } & \text { video } \\ \text { pembelajaran } & \text { terbukti } & \text { dapat } \\ \text { meningkatkan } & \text { aktvitas } & \text { siswa, } \\ \text { sehingga hasil belajar IPS } & \text { dapat }\end{array}$
ditingkatkan. Dalam penelitian ini dilaksanakan sebanyak tiga siklus, karena pada siklus III data yang diperoleh sudah mencapai indikator keberhasilan yang sudah ditentukan. Berikut ini akan dipaparkan hasil penelitian yang terdiri atas observasi aktivitas siswa, dan hasil belajar IPS dengan menerapkan media video pembelajaran dengan materi persiapan kemerdekaan Indonesia pada siswa kelas VB SDN Mampang Prapatan 02. Sebelum tes evaluasi IPS digunakan untuk penelitian, terlebih dahulu diadakan uji validitas isi, reliabilitas, daya pembeda dan tingkat kesukaran. Hasil yang diperoleh sebagai berikut.

Hasil pengamatan aktivitas siswa pada siklus I dalam proses pembelajaran terdapat 4 aspek indikator yang diamati dengan skor 27,75 dengan nilai kategori cukup. Prosentasi ketuntasan aktivitas siswa kelas VB dalam mata pelajaran IPS yaitu sebesar 37,50\%. Aspek yang diamati meliputi: (1) Kesiapan dalam menerima pelajaran (emotional activities); (2) Kemampuan siswa dalam memahami materi yang diberikan dalam bentuk media video pembelajaran (emotional activities, mental activities, listening activities); (3) Keaktifan siswa dalam mengikuti pembelajaran dengan menggunakan media video (visual activities, mental activities, oral activities, listening activities).

Aktivitas siswa pada siklus II mengalami peningkatan dengan pencapaian skor 32,25 dengan nilai kategori baik. Pada siklus II terdapat 4 aspek aktivitas siswa yang diamati. Prosentasi ketuntasan aktivitas siswa kelas VB dalam mata pelajaran IPS yaitu sebesar 58,33\%. Aspek yang diamati meliputi: (1) Kesiapan dalam menerima pelajaran (emotional activities); (2) Kemampuan siswa dalam memahami materi yang diberikan dalam bentuk media video pembelajaran (emotional activities, mental activities, listening activities); (3) Keaktifan siswa dalam mengikuti pembelajaran dengan menggunakan media video (visual activities, mental 
activities, oral activities, listening activities).

Aktivitas siswa pada siklus III mengalami peningkatan yang signifikan dengan pencapaian skor 33,625 dengan nilai kategori baik. Prosentasi ketuntasan aktivitas siswa kelas VB dalam mata pelajaran IPS yaitu sebesar 83,30\%. Aspek yang diamati meliputi: (1) Kesiapan dalam menerima pelajaran (emotional activities); (2) Kemampuan siswa dalam memahami materi yang diberikan dalam bentuk media video pembelajaran (emotional activities, mental activities, listening activities); (3) Keaktifan siswa dalam mengikuti pembelajaran dengan menggunakan media video (visual activities, mental activities, oral activities, listening activities).

Bila ditinjau dari hasil observasi aktivitas siswa dalam mengelola pembelajaran IPS melalui media video mengalami peningkatan ratarata skor pada siklus I yaitu 27,75 dengan kategori cukup, sikus II yaitu 32,25 dengan kategori baik, dan pada siklus III yaitu 33,625 dengan kategori sangat baik, sehingga dapat meningkatkan aktivitas siswa dalam mengelola pembelajaran. Peningkatan aktivitas siswa siklus I, siklus II dan siklus III dapat dilihat pada diagram 1.

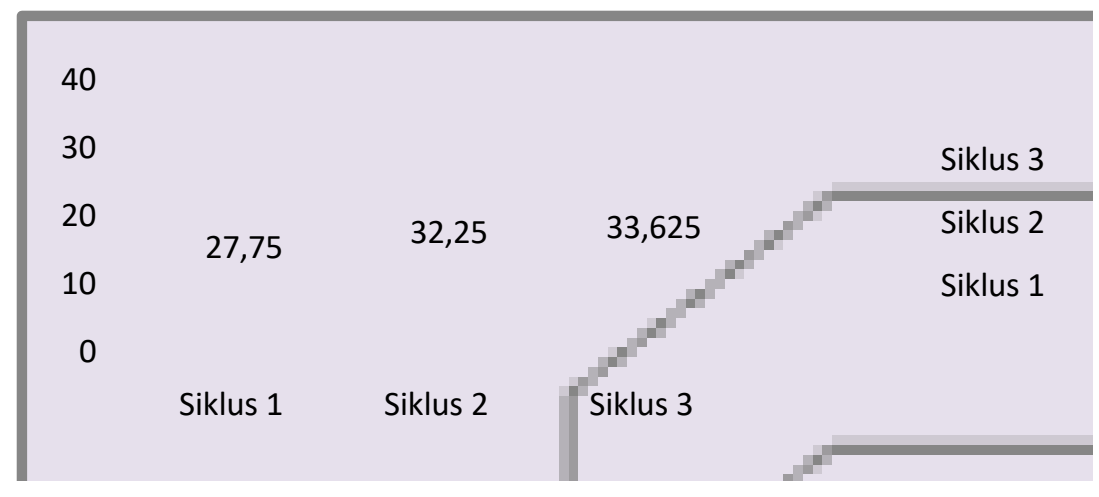

Gambar1. Peningkatan Aktivitas Siswa

Berdasarkan hasil evaluasi mengalami peningkatan pada tahap pembelajaran IPS pada siswa kelas tindakan kelas yaitu pada siklus I, VB SDN Mampang Prapatan 02 siklus II dan siklus III dibandingkan diperoleh nilai rata-rata yang pada saat pra siklus. Hasil belajar 
pada pra siklus dalam kategori rendah dengan ketuntasan klasikal yaitu $16,66 \%$, rata-rata 55,83 . Jumlah siswa yang tuntas sebanyak 4 dari 24 siswa dan yang tidak tuntas sebanyak 20 dari 24 siswa. Siklus I dalam kategori rendah dengan ketuntasan klasikal yaitu 29,10\% rata-rata 58,33. Perolehan nilai tertinggi 90 dan nilai terendah 40. Siswa yang memenuhi KKM adalah 7 siswa. Dengan perolehan hasil belajar seperti di atas, peneliti masih perlu melakukan penelitian tindakan untuk siklus selanjutnya. Di karenakan dari 24 siswa yang tuntas sesuai dengan nilai $\operatorname{KKM}(\mathrm{KKM}=70)$ adalah 14 orang.

Siklus II dalam kategori tinggi dengan ketuntasan klasikal yaitu $66,60 \%$, rata-rata 68,75 . Perolehan nilai tertinggi 90 dan nilai terendah 50. Siswa yang memenuhi KKM adalah 17 siswa. Dengan perolehan hasil belajar seperti di atas, peneliti masih perlu melakukan penelitian tindakan untuk siklus selanjutnya. Di karenakan dari 24 siswa yang tuntas sesuai dengan nilai KKM (KKM= 70) adalah 7 orang. Siklus III dalam kategori tinggi dengan ketuntasan klasikal yaitu 83,30\%, rata-rata
80,83 . Perolehan nilai tertinggi 90 dan nilai terendah 60. Siswa yang memenuhi KKM adalah 20 siswa. Dengan perolehan hasil belajar seperti di atas, peneliti masih perlu melakukan penelitian tindakan untuk siklus selanjutnya. Di karenakan dari 24 siswa yang tuntas sesuai dengan nilai $\mathrm{KKM}(\mathrm{KKM}=70)$ adalah 4 orang. Hasil tersebut sudah memenuhi kriteria indikator keberhasilan yang direncanakan yaitu $75 \%$ siswa tuntas belajar dengan memenuhi Kriteria Ketuntasan Minimal (KKM) yaitu 70.

Hasil belajar pada pembelajaran IPS pra siklus terdapat 20 siswa yang belum tuntas, siklus I terdapat 14 siswa yang belum tuntas, siklus II terdapat 7 siswa yang belum tuntas, sedangkan siklus III terdapat 4 siswa yang belum tuntas. Pada siklus III dari aktivitas siswa dalam pembelajaran dikategorikan baik, serta hasil belajar siswa dalam pembelajaran IPS dikategorikan sangat baik, sebagian besar siswa sudah mencapai batas Kriteria Ketuntasan Minimal (KKM) yang ditentukan sekolah yaitu 70 serta 
mencapai rata-rata kelas 80,83 dengan ketuntasan klasikal 83,30\%. Indikator keberhasilan pembelajaran di siklus III sudah tercapai, maka kegiatan pembelajaran pada siklus III dirasa cukup dan penelitian berhenti di siklus III. Dalam penelitian ini sudah sesuai dengan pendapat
Hamalik (2009: 112) yang menyatakan bahwa hasil belajar adalah bila seseorang telah belajar akan terjadi perubahan tingkah laku pada orang tersebut, misalnya dari tidak tahu menjadi tahu, dan dari tidak mengerti menjadi mengerti.

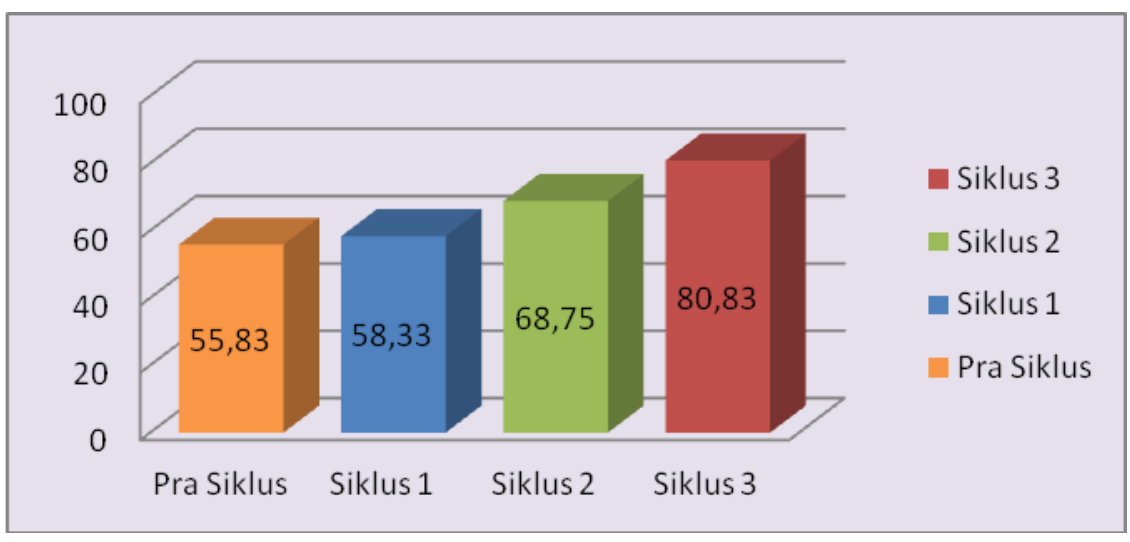

Gambar2. Peningkatan Aktivitas Siswa

\section{PENUTUP}

Berdasarkan hasil penelitian tindakan kelas aktivitas siswa dan hasil belajar siswa pada pembelajaran IPS dengan menggunakan media video pada siswa kelas VB SDN Mampang Prapatan 02, maka dapat disimpulkan sebagai berikut: (1) Aktivitas siswa dalam pembelajaran IPS melalui media video dapat meningkat dilihat dari pembelajaran siklus I aktivitas siswa memperoleh rata-rata 27,75 dalam kategori cukup, setelah dilakukan perbaikan pada siklus II aktivitas siswa meningkat 4,5, sehingga diperoleh skor 32,25 dalam kategori baik, selanjutnya dilakukan perbaikan pada siklus III aktivitas siswa memperoleh peningkatan mencapai 1,375, sehingga diperoleh rata-rata skor 33,625 dalam kategori sangat baik; dan (2) Hasil belajar siswa dalam pembelajaran IPS 
melalui media video mengalami peningkatan yang signifikan dapat dilihat pada saat pra siklus dengan pencapaian rata-rata kelas sebesar 55,83 dengan ketuntasan klasikalnya $16,66 \%$ dalam kategori rendah. Setelah diadakan perbaikan pada siklus I, pencapaian rata-rata kelas sebesar 58,33 dengan ketuntasan klasikal 29,10\% dalam kategori rendah. Kemudian setelah diadakan perbaikan pada pada siklus II, pencapaian rata-rata hasil belajar siswa meningkat sebesar 10,42 sehingga menjadi 68,75 dengan ketuntasan klasikal $66,60 \%$ dalam kategori tinggi. Setelah diadakan perbaikan lagi, pencapaian rata-rata hasil belajar siswa pada siklus III meningkat sebesar 2,47 sehingga menjadi 80,83 dengan ketuntasan klasikal 83,30\% dalam kategori sangat baik.

\section{DAFTAR PUSTAKA}

Arikunto, S. (2006). Prosedur Penelitian. Jakarta: Asdi Mahasatya
Dasar Evaluasi Pendidikan. Jakarta: Bumi Aksara

(2014).

Penelitian Tindakan Kelas. Jakarta: Bumi Aksara.

Azwar, S. (2013). Reliabilitas dan Validitas. Yogyakarta: Pustaka Pelajar.

Daryanto. (2010). Media Pembelajaran. Yogyakarta: Gava Media.

Hamalik, O. (2009). Proses Belajar Mengajar. Jakarta: Bumi Aksara.

Heriyanto, et al. (2007). Statistika Dasar. Jakarta: Universitas Terbuka.

Hidayati, et al. (2008). Pengembangan Pendidikan IPS SD. Jakarta: Dirjendikti Depdiknas.

PGSD FIP UNNES. (2011). Kreatif Jurnal Kependidikan Dasar Volume 1. Semarang: Jurusan PGSD FIP UNNES.

Poerwanti, E., et al. (2008). Asesmen Pembelajaran SD. Jakarta: Depdiknas.

Sardiman. (2010). Interaksi dan Motivasi Belajar-Mengajar. Jakarta: Rajawali Pers.

Sugiyono. (2010). Metode Penelitian Pendidikan. Bandung: Alfabeta.

Surapranata, S. (2005). Analisis Validitas, Reliabilitas, dan Interpretasi Hasil Tes Kurikulum 2004. Bandung: PT. Remaja Rosdakarya. 